\title{
Internet sociology: Impact of Facebook addiction on the lifestyle and other recreational activities of the Indian youth
}

\author{
${ }^{1}$ Y.A. Modi \& ${ }^{1}$ I.S. Gandhi \\ ${ }^{1}$ School Of Liberal Studies, Pandit Deendayal Petroleum University, Gandhinagar, Gujarat, India.
}

\begin{abstract}
Background: In March 2013 Facebook announced it had around 1.1 billion monthly active users, this number has been growing exponentially from $40 \%$ in 2011 and it is estimated to pass $70 \%$ mark in 2013 . Most of these users being young, the impact of Facebook addiction can clearly be expected to alter their lifestyle. Objectives: • To examine the impact Facebook addiction (IV) on the recreational activities (DV). $\bullet$ To identify the effects of Facebook addiction on the well-being of the Indian youth. Methods: Empirical research using descriptive analysis was conducted on more than 100 college students. Findings: Greater percentage of the population is at threat to get addicted or is already addicted to Facebook. Activities affected due to Facebook usage were identified and categorized. Anger, frustration, boredom and sadness were the possible variables reported by respondent incase of forceful reduction of Facebook usage.
\end{abstract}

\section{Introduction}

"Social Networking Sites (SNS) are virtual commu-nities where users can create individual public pro-files, interact with real-life friends, and meet other people based on shared interests (Boyd \& Ellison 2008). While according to the Merriam-Webster dic-tionary, addiction is compulsive need for and use of a habit-forming substance characterized by tolerance and by well-defined physiological symptoms upon withdrawal (MerriamWebster, Dictionary).

In the last few years, SNS have been called a global consumer phenomenon owing to the expo-nential rise in their usage (The Nielson Company 2009). Anecdotal case studies have shown that ad-diction to SNS can prove to be a threat to the physiological and psychological wellbeing of some users (Kuss \& Griffiths 2011). The concept of social networking addiction is gradually gaining acceptance as a legitimate clinical disorder over the past decade.

Today, with the unimaginable growth and easy access to technology, people keep looking for ways to find new friends and connect with their family members, friends, co-workers and classmates. One of the most commonly used sites for the same is Fa-cebook (Sherman 2011). Being the most used social networking site in India, Facebook currently has more than 52 million Indian users as stated by the Digital Strategy Consulting in December 2012. Ap-proximately $52 \%$ users are between the age group of 18 to 34 . Hence this paper studies the impact of Facebook addiction as it can clearly be expected to alter the lifestyle of today's youth.
Facebook has a lot of positive aspects from allow-ing people to be social and updated to connecting with friends and family in different parts of the world. However, there is a certain amount time and energy one devotes to Facebook. When an individu-al irrationally increases this time and energy, such that they alter their lifestyle, work, performance and show withdrawal symptoms when forced to reduce the usage of Facebook, it becomes an alarming con-cern for the society.

The symptoms of Facebook addiction may range from mood modification, salience, tolerance, conflict and relapse to neglect of personal life, mental preoccupation and escapism (Young 2009). Moreo-ver recent cases of rape, profile hacking, negative ef-fects on various relationships etc caused due to abuse of Facebook, as reported in the Times of India highlight the need to study the negative effects of Facebook Addiction (The Times Of India, in press).

Also the new internet generation is losing touch with the traditional ways of recreation such as going outside, playing with friends, reading a book etc. Our study explores the activities people are missing out on due to the excessive usage of Facebook.

\section{Methods}

\subsection{Procedures}

Descriptive analysis was conducted on primary data collected by using survey method. The participants were 100 multi-cultural Indian undergraduate col-lege students 
who were active Facebook users and studying at a private university in Gujarat, India. The age range was 17-24 years with the average age of 19 years. The gender distribution of the sample was as follows: $77 \%$ male $\&$ $23 \%$ female.

\subsection{Instruments/Tools}

The instruments used were 2 questionnaires: 1. Facebook Addiction Test: This test was constructed on the basis of the Internet Addiction Test (IAT) and was administered on the participants. IAT developed by Dr. Kimberly Young measures the extent of cli-ent's involvement with the computer and classifies the addictive behavior in terms of mild, moderate and severe impairment. The psychometric properties of the IAT show that it is a reliable and valid meas-ure (Widyanto \& McMurren 2004). 2. Impact of ad-diction questionnaire: This was an alternative ques-tionnaire asking people what they are missing out on due to excessive usage of Facebook. It also included open-ended questions like what the participant would feel or do if their Facebook usage was to be forcefully reduced.

\subsection{Variables}

The Independent variable for the research was the level of Facebook addiction of the participant while the dependent variable was the impact of Facebook addiction on the recreational activities of the participants.

\section{Figures and tables}

According to the participants' score of the Facebook addiction test, the sample was classified into four levels of addiction. These levels were formulated calculating the mean and standard deviation of the total population. The average addiction score was found to be 41.56 and the standard deviation was 14.05

Table 1. Levels of addiction identified by calculating standard deviation

\begin{tabular}{lll}
\hline Levels of Addiction & & \\
\hline Addiction score & Classification & Social \\
\hline $12--25$ & Low & Interaction \\
$26-54$ & Average & \\
$55-68$ & High & \\
$69-82$ & Very high & \\
\hline
\end{tabular}

According to the addiction score distribution, it was observed that $18 \%$ of the sample had above average addiction (14\% high addiction and 4\% very high addiction) while $15 \%$ had below average addiction score.

Table 2. Addiction score distribution

\begin{tabular}{ll}
\hline Level of Addiction & Frequency (in percentage) \\
\hline Low & $15 \%$ \\
Average & $67 \%$ \\
\hline
\end{tabular}

\begin{tabular}{ll}
\hline High & $14 \%$ \\
Very High & $4 \%$ \\
\hline
\end{tabular}

\subsection{Based on the Impact of addiction questionnaire}

Activities missed out due to the excessive usage of Facebook were grouped into four broad categories as follows: 1. Leisure Activities: These included recreational activities like watching television, listening to music, watching movies, gaming, enjoying nature and going to shopping malls. 2. Arts/Interests: These included hobbies like reading, dancing, drawing, painting, writing, sports and cooking. 3. Social Interaction: These included activities like talking on the phone, face to face interaction, spending time with family, hanging out with friends, celebrating festivals and indulging in non virtual relationships or socializing. 4. Health and Self Care: These included day-to-day tasks like eating, self grooming, exercise, sleep and household chores. Academics was also said to be missed out by a large percentage of the population.

Table 3. Activities people missed out on due to excessive usage of Facebook

\begin{tabular}{|c|c|c|}
\hline Categories & $\begin{array}{l}\text { Activities missed } \\
\text { out }\end{array}$ & $\begin{array}{l}\text { Frequency (in } \\
\text { percentage) }\end{array}$ \\
\hline \multirow{6}{*}{ Arts/Interests } & Cooking & $20 \%$ \\
\hline & Sports & $28 \%$ \\
\hline & Writing & $28 \%$ \\
\hline & Drawing/Painting & $20 \%$ \\
\hline & Dancing & $14 \%$ \\
\hline & Reading & $58 \%$ \\
\hline \multirow{5}{*}{$\begin{array}{l}\text { Health \& Self } \\
\text { Care }\end{array}$} & Sleeping & $39 \%$ \\
\hline & Self Grooming & $15 \%$ \\
\hline & Eating & $13 \%$ \\
\hline & Household Chores & $11 \%$ \\
\hline & Exercise & $25 \%$ \\
\hline \multirow{8}{*}{$\begin{array}{l}\text { Social } \\
\text { Interaction }\end{array}$} & Family Time & $32 \%$ \\
\hline & $\begin{array}{l}\text { Hanging out with } \\
\text { friends }\end{array}$ & $33 \%$ \\
\hline & Face to Face & $40 \%$ \\
\hline & Interaction & \\
\hline & Celebrating & $10 \%$ \\
\hline & Festivals & \\
\hline & $\begin{array}{l}\text { Talking on the } \\
\text { phone }\end{array}$ & $28 \%$ \\
\hline & $\begin{array}{l}\text { Non Virtual } \\
\text { Relationships }\end{array}$ & $19 \%$ \\
\hline \multirow{6}{*}{$\begin{array}{l}\text { Leisure } \\
\text { Activities }\end{array}$} & Gaming & $27 \%$ \\
\hline & Movies & $24 \%$ \\
\hline & Music & $23 \%$ \\
\hline & Watching Tv & $27 \%$ \\
\hline & $\begin{array}{l}\text { Going to shopping } \\
\text { malls }\end{array}$ & $8 \%$ \\
\hline & Enjoying Nature & $20 \%$ \\
\hline Academics & Studying & $48 \%$ \\
\hline
\end{tabular}


It was observed that maximum number of people missed out on activities like reading $(58 \%)$, face to face interaction (40\%) and sleeping (39\%) while activities like going to shopping malls, celebrating festivals and household chores were least missed.

On categorical analysis of the data, we could conclude that activities falling under academics, arts/interests and social interaction were comparatively missed out the most followed by leisure activities and health $\&$ self care activities respectively.

For further qualitative analysis of the data, the sample was asked how they would feel if their Facebook usage was to be forcibly reduced. Evaluating their responses we found that approximately $46 \%$ of the sample would experience Anger, Frustration, Sadness or Boredom. Surprisingly around $15 \%$ of the people said that they would feel Happier if their Facebook usage was forcibly reduced as they would have more time for other activities. While many others stated that it would not make much of a difference to them.

\section{Results}

\subsection{Discussion}

"Use, do not abuse; neither abstinence nor excess ever renders man happy"-Voltaire

Facebook usage has a lot of positive effects; however its excessive usage may lead to addiction. Addic-tion is known to destroy human beings and their rela-tionships. Internet addiction is no exception (Kim \& Kim 2002).

Through this study we found that the percentage of participants having higher addiction score were more than those having a lower addiction score. Hence keeping in mind the increasing usage of Facebook, we can establish that a greater percentage of the popula-tion is at threat to get addicted to Facebook or is al-ready addicted to Facebook.

It could be concluded that academics and social interaction are most affected due to the excessive usage of Facebook. A similar observation was also seen in a recent study assessing the relationship between Face-book usage and academic performance where Face-book users were seen to spend less time studying than the other students (Kirschner \& Karpinski 2012). Moreover results from an online survey also estab-lished that people who spent more time on SNS were perceived to be less involved with their real life com-munities (Nyland et al. 2007).

Dr. Kimberly Young's study on Internet Addiction highlights the impact of the addiction on health and self care as she establishes that addicts typically dis-rupt their sleep patterns which may result in lack of proper exercise (Young 1999). Through our study we could observe similar impact on Facebook addiction as the other categories like leisure activities, health and self care and arts/interests were also affected with the excessive usage.

Through qualitative analysis it could be determined that the participant's emotional state would be ham-pered if Facebook was to be forcefully reduced. While most of them expressed feelings of Anger, Frustration, Boredom and Sadness; there were some who would be happier or remain unaffected by the change.

\subsection{Limitations and proposed further study}

Activities missed out due to the excessive usage of Facebook were grouped into four broad categories as follows: 1. Leisure Activities: These included recreational activities like watching television, listening to music, watching movies, gaming, enjoying nature and going to shopping malls. 2. Arts/Interests: These included hobbies like reading, dancing, drawing, painting, writing, sports and cooking. 3. Social Interaction: These included activities like talking on the phone, face to face interaction, spending time with family, hanging out with friends, celebrating festivals and indulging in non virtual relationships or socializing. 4. Health and Self Care: These included day-to-day tasks like eating, self grooming, exercise, sleep and household chores. Academics was also said to be missed out by a large percentage of the population.

\section{References}

1. Boyd, D.M., \& Ellison, N.B. 2008. Social network sites: Definition, history, and scholarship. J. Comput. Mediat. Comm., 13, 210-230.

2. Kim S. \& Kim R. 2002. A Study of Internet Addiction: Status, Causes, and Remedies, Journal of Korean Home Economics Association English Edition : Vol. 3, No. 1, December 2002.

3. Kirschner, P.A., \& Karpinski, A.C. 2012. Facebook and academic performance. Comput. Hum. Behav., 26, 1237-1245.

4. Kuss, D. J., \& Griffiths M. D. 2011. Online Social Networking and Addiction- a review of the psychological literature, Int. J. Environ. Res. Public Health 2011, 8, 3528-3552.

5. Merriam Webster Dictionary (n.d.). Addiction Definition and More. Dictionary and Thesaurus - Merriam-Webster Online. Retrieved August 24, 2013.

6. Nyland, R., Marvez, R., \& Beck, J. 2007. MySpace: Social networking or social isolation? In Proceedings of the Midwinter Conference of the Association for Education in Journalism and Mass Communication, Midwinter Conference of the Association for Education in Journalism and Mass Communication, Reno, NV, USA, 23-24 February 2007.

7. Sherman, E. 2011. Facebook Addiction: Factors Influencing an Individual's Addiction. Honors Thesis Program in the college of Management Paper 5. 
8. The Nielsen Company. 2009. Global Faces and Networked Places; Available online:

http://blog.nielsen.com/nielsenwire/wpcontent/u ploads/2009/03/nielsen_globalfaces_mar09.pdf (accessed on 18 August 2011).

9. The Times of India. (n.d.). 2 men gang-rape girl in Kota after befriending her on Facebook Featured Articles From The Times Of India. Retrieved August 24, 2013

10. Times of India. (n.d.). FIR filed for hacking teacher's Facebook profile - The Times of India: Latest News India, World \& Business News, Cricket \& Sports, Bollywood. Retrieved August 24, 2013

11. Widyanto, L., \& McMurren, M. 2004. The psychometric properties of the Internet addiction test, CyberPsychology \& Behavior, 7(4):445453.

12. Young, K. 1999. Internet addiction: Evaluation and treatment. Student Brit. Med. J., 7, 351-352.

13. Young, K. 2009. Facebook Addiction Disorder?; The Center for Online Addiction: Bradford, PA, USA,2009; Available online: http://www.netaddiction.com/index.php?option= com_blog\&view $=$ comments \&pid $=5 \&$ Itemid $=0$ (accessed on 29 November 2010).

14. F. De Lillo, F. Cecconi, G. Lacorata, A. Vulpiani, EPL, 84 (2008)

15. L. T. De Luca, Propulsion physics (EDP Sciences, Les Ulis, 2009) 